\title{
Fine mapping and identification of candidate genes for the $s y-2$ locus in a temperature-sensitive chili pepper (Capsicum chinense)
}

\author{
Li Liu ${ }^{1} \cdot$ Jelli Venkatesh $^{1} \cdot$ Yeong Deuk $\mathrm{Jo}^{1} \cdot$ Sota Koeda $^{2} \cdot$ Munetaka Hosokawa $^{2}$ • \\ Jin-Ho Kang ${ }^{3}$ Sandra Goritschnig ${ }^{4}$ Byoung-Cheorl Kang ${ }^{1}$
}

Received: 26 February 2016 / Accepted: 22 April 2016 / Published online: 4 May 2016

(C) Springer-Verlag Berlin Heidelberg 2016

\begin{abstract}
Key message The sy-2 temperature-sensitive gene from Capsicum chinense was fine mapped to a $138.8-\mathrm{kb}$ region at the distal portion of pepper chromosome 1 . Based on expression analyses, two putative F-box genes were identified as $\boldsymbol{s} \boldsymbol{y} \mathbf{2}$ candidate genes.

Abstract Seychelles-2 ('sy-2') is a temperature-sensitive natural mutant of Capsicum chinense, which exhibits an abnormal leaf phenotype when grown at temperatures below $24{ }^{\circ} \mathrm{C}$. We previously showed that the $s y-2$ phenotype is controlled by a single recessive gene, $s y-2$, located on pepper chromosome 1. In this study, a high-resolution genetic and physical map for the $s y-2$ locus was constructed using two individual $\mathrm{F}_{2}$ mapping populations derived from a cross between $C$. chinense mutant 'sy-2' and wild-type 'No. 3341'. The sy-2 gene was fine mapped to a $138.8-\mathrm{kb}$
\end{abstract}

Communicated by R. G.F. Visser.

Electronic supplementary material The online version of this article (doi:10.1007/s00122-016-2723-1) contains supplementary material, which is available to authorized users.

Byoung-Cheorl Kang

bk54@snu.ac.kr

1 Department of Plant Science and Plant Genomics and Breeding Institute, Seoul National University, Seoul 151-921, Korea

2 Department of Agronomy and Horticultural Science, Graduate School of Agriculture, Kyoto University, Sakyo-ku, Kyoto 606-8502, Japan

3 Crop Biotechnology Institute/GreenBio Science and Technology, Seoul National University, Pyeongchang 232-916, Korea

4 Keygene N.V., P.O. Box 216, 6700 AE Wageningen, The Netherlands region between markers SNP 5-5 and SNP 3-8 at the distal portion of chromosome 1, based on comparative genomic analysis and genomic information from pepper. The $s y-2$ target region was predicted to contain 27 genes. Expression analysis of these predicted genes showed a differential expression pattern for ORF10 and ORF20 between mutant and wild-type plants; with both having significantly lower expression in ' $s y-2$ ' than in wild-type plants. In addition, the coding sequences of both ORF10 and ORF20 contained single nucleotide polymorphisms (SNPs) causing amino acid changes, which may have important functional consequences. ORF10 and ORF20 are predicted to encode F-box proteins, which are components of the SCF complex. Based on the differential expression pattern and the presence of nonsynonymous SNPs, we suggest that these two putative F-box genes are most likely responsible for the temperature-sensitive phenotypes in pepper. Further investigation of these genes may enable a better understanding of the molecular mechanisms of low temperature sensitivity in plants.

\section{Introduction}

Drought, heat, cold, and salinity are among the major abiotic stresses that can adversely affect the growth and development of plants (Dwivedi et al. 2008; Ismail et al. 2007; Ramegowd and Senthil-Kumar 2015). Among these, temperature is one of the main environmental factors affecting the productivity and geographical distribution of crops (Miura and Furumoto 2013; Thakur et al. 2010; Theocharis et al. 2012). To mitigate or avoid potential damage caused by these stresses, plants must effectively sense, respond to, and adapt to changes in their environment by altering their physiological, biochemical, and/or genetic characteristics 
(Arbona et al. 2013; Shinozaki and Yamaguchi-Shinozaki 2000; Wang et al. 2013).

Low temperature affects many plant physiological processes, such as water and nutrient uptake, photosynthesis, plant growth, and development (Chinnusamy et al. 2007; Harfied and Prueger 2015). Plant species are able to alleviate the unfavorable effects of low, non-freezing temperatures through a complex adaptive mechanism known as cold acclimation, which is associated with many biochemical and physiological changes (Chinnusamy et al. 2010; Miura and Furumoto 2013; Theocharis et al. 2012). To understand the molecular basis of low temperature sensitivity in plants, several low temperature-sensitive mutants have been explored. The Arabidopsis thaliana fatty acid desaturase 2 (fad2) mutant deficient in the endoplasmic reticulum (ER) 18:1 desaturase, shows abnormal leaves and a severe dwarf phenotype under low temperature due to the disintegration of the cell membrane (Miquel and Browse 1994; Zhang et al. 2012). The Arabidopsis nonphotochemical quenching 1 (npql) mutant, which is deficient in xanthophyll cycling, exhibits an accumulation of excessive oxidative stress causing the inhibition of photo system II (PSII) at low temperature (Havaux and Kloppstech 2001). The tobacco temperature dependent shooty ( $t d s)$ mutant displays abnormal mesophyll cells, thick narrow leaves, and shorter internodes when grown at low temperature (Samuelsen et al. 1997). The Arabidopsis bonzail (bonl) null mutants produce miniature fertile plants, and the $B O N 1$ and $B A P I$ (BON1-associated protein) genes were suggested to have a direct role in regulation of cell expansion and cell division at lower temperatures (Hua et al. 2001). The mutant maize inbred line M11 shows remarkably lower accumulation of chlorophyll, which is associated with impaired development and function of chloroplasts (Millerd and McWilliam 1968). The rice low temperature albino 1 (ltal) mutant has albino leaves characterized by remarkably reduced contents of chlorophyll and chlorophyll precursor molecules (Peng et al. 2012). Thus, low temperature responses in plants involve many aspects of plant physiology, many different metabolic pathways, and complex genetic interactions that make the study of a plant's response to low temperature stress challenging.

Pepper, an important vegetable crop grown worldwide, is temperature-sensitive; its optimum growth temperature lies between 25 and $30{ }^{\circ} \mathrm{C}$, and deviations from these temperatures can adversely affect growth and development, resulting in a variety of developmental and physiological disorders. The $C$. chinense cultivar 'sy-2' is a local pepper landrace from the Seychelles that was previously found to be temperature-sensitive, showing developmental abnormalities when grown at temperatures lower than $24{ }^{\circ} \mathrm{C}$ (Koeda et al. 2009). Specifically, the 'sy-2' cultivar exhibits abnormal leaf growth characterized by the development of thicker and narrower cotyledons with fewer palisade cells along both the length and width of the leaf lamina, but more cells in depth (Koeda et al. 2009). The 'sy-2' plant exhibits chlorophyll deficiency due to abnormal chloroplast structures and cell collapse (An et al. 2011). In addition, excessive accumulation of reactive oxygen species (ROS) resulting in cell death is observed in the chlorophyll-deficient sectors of the leaves from ' $s y-2$ ' plants grown at $20{ }^{\circ} \mathrm{C}$. Analysis of the fatty acid content of 'sy-2' leaves showed an impaired pathway for conversion of linoleic acid (18:2) to linolenic acid (18:3) (An et al. 2011). Further, transcriptome analysis of the 'sy-2' cultivar in response to temperatures below $24{ }^{\circ} \mathrm{C}$ showed that a quarter of the upregulated genes were defense related or predicted to be defense related (Koeda et al. 2013). However, the precise molecular and biochemical basis of the cold temperature sensitivity in 'sy-2' plants is not clearly understood.

We have previously shown that a single recessive gene localized to the $300-\mathrm{kb}$ region of the tomato Ch1_scaffold 00106 controls the 'sy-2' phenotype. However, the exact location of the corresponding genomic region in pepper was not determined (An et al. 2011). In this study, we implemented a map-based cloning approach using two $F_{2}$ populations derived from $C$. chinense 'sy-2' and wild-type C. chinense 'No. 3341 ' to generate a high-density linkage map of the sy-2 locus on pepper chromosome 1. Fine mapping of the locus allowed us to position the putative gene to an approximately $138.8-\mathrm{kb}$ region flanked by markers SNP 5-5 and SNP 3-8. This study aimed to identify sy-2 candidate genes, with the ultimate goal to elucidate the molecular mechanism responsible for the temperature sensitivity of the 'sy-2' cultivar.

\section{Materials and methods}

\section{Plant materials and growth conditions}

Two $\mathrm{F}_{2}$ mapping populations, containing $1020\left(2012 \mathrm{~F}_{2}\right)$ and 1433 lines $\left(2014 \mathrm{~F}_{2}\right)$, were constructed from a cross between $C$. chinense 'sy-2' and $C$. chinense 'No. 3341' and were used for linkage and genetic mapping analyses. For the genetic analysis, all seeds were sterilized and germinated in an incubator at $30{ }^{\circ} \mathrm{C}$ in dark conditions. Oneweek-old seedlings were transferred to a growth chamber at $28{ }^{\circ} \mathrm{C}$ with $16-\mathrm{h}$ light and 8-h dark cycles until the cotyledons were fully expanded. The seedlings were then transferred to $20{ }^{\circ} \mathrm{C}$ chambers, screened for a low temperaturesensitive phenotype after 14 days, and then leaf samples were collected for DNA extraction. For the RNA-seq analysis, leaf samples from 63 wild-type and 30 mutant phenotype plants from the $2014 \mathrm{~F}_{2}$ population were collected 
for RNA extraction. For RT-PCR and qPCR analyses, leaf samples from 'sy-2' and 'No. 3341' plants grown at 20 and $28^{\circ} \mathrm{C}$ were used.

\section{Comparative map and sequence analysis}

Based on the map position of the $s y-2$ locus on chromosome 1 (An et al. 2011; Koeda et al. 2012, 2013), the sy-2 gene was flanked by the COSII markers C2_At4g29120 and C2 At1g09070 at a distance of 1.6 and $3.1 \mathrm{cM}$, respectively. These two COSII markers were identified and located at 3.7 and $4.0 \mathrm{cM}$ on chromosome 1 of Tomato-EXPEN 2000 (http//:solgenomics.net) (An et al. 2011). A tomato scaffold sequence (C01HBa0051C14) of 126,295 base pairs (bp) in length, covering the corresponding region of the sy-2 locus, was identified based on the C2_At1g09070 and C2_At4g29120 markers obtained from Sol Genomic Network (SGN, http//:solgenomics.net). Gene coding regions of the tomato scaffold were predicted by FGENESH (http://linux1.softberry.com). The predicted amino acid sequences were used to search for annotated genes using the BLASTP program (http://www.ncbi.nlm.nih.gov). The sequences of gene coding regions were then used to search for the homologous pepper sequences from the $C$. аппиит genome database (http://cab.pepper.snu.ac.kr). Based on these analyses, three pepper scaffold sequences, scaffold $2607(377.7 \mathrm{~kb})$, scaffold $3515(200.8 \mathrm{~kb})$, and scaffold $2510(318.6 \mathrm{~kb})$, were identified in the database (http://cab. pepper.snu.ac.kr).

\section{Development of SNP markers}

Genomic DNA was extracted with a hexadecyltrimethylammonium bromide (CTAB) procedure (Hwang et al. 2009). Genomic DNA samples from two mapping populations were used to map the $s y-2$ gene using SNP markers. Primers were manually designed in intergenic regions based on the three pepper scaffold sequences using the Primer Select program (DNASTAR, Inc., Madison, WI, United States) with an amplicon size of approximately $1 \mathrm{~kb}$. PCR was carried out in a thermocycler (My Cycler ${ }^{\mathrm{TM}}$, BioRad, USA). PCR reactions were performed in a total volume of $50 \mu 1$ containing $10 \mu \mathrm{l}$ DNA (10 ng/ $\mu \mathrm{l}), 5 \mu \mathrm{l} 10 \times$ Ex Taq PCR buffer (TaKaRa, Japan), $4 \mu 12.5 \mathrm{mM}$ dNTP mixture (TaKaRa), $0.4 \mu l$ Ex Taq polymerase (TaKaRa, Japan), $2 \mu l 10 \mathrm{pmol} / \mu \mathrm{l}$ each primer and $26.6 \mu \mathrm{l}$ distilled water. PCR conditions involved denaturing the DNA for $4 \mathrm{~min}$ at $95{ }^{\circ} \mathrm{C}$, followed by 35 cycles of $30 \mathrm{~s}$ at $95{ }^{\circ} \mathrm{C}, 30 \mathrm{~s}$ at $55-58{ }^{\circ} \mathrm{C}$, and $40 \mathrm{~s}$ at $72{ }^{\circ} \mathrm{C}$, and a final extension time of 10 min at $72{ }^{\circ} \mathrm{C}$. Purified PCR products were sequenced at NICEM (National Instrumentation Center for Environmental Management, Seoul National University, Seoul, Korea). Nucleotide sequences of wild-type and 'sy-2' plants were aligned using the SeqMan program (DNASTAR, Inc., Madison, WI, United States) to detect SNPs. SNP markers were manually designed with amplicon sizes smaller than $250 \mathrm{bp}$, and where possible, transformed into HRM and KASP markers (Table S1).

\section{BAC library screening and sequencing analysis}

A C. апnиит 'CM334' BAC library of $12 \times$ genome coverage $(99 \%)$ with 235,000 clones and an average insert size of $130 \mathrm{~kb}$ (Yoo et al. 2003) was used to close the gaps between the scaffolds. These sequence gaps were closed using BAC clones identified by end sequences of the three pepper scaffolds. Primer sequences are listed in Table S2. A total of 21 positive BAC clones containing scaffold sequences were selected and $\mathrm{BAC}$ end sequences were determined at NICEM using $\mathrm{SP}_{6}$ and $\mathrm{T}_{7}$ primers. The $\mathrm{BAC}$ end sequences located at extended regions were used to search for homologues of pepper sequences from the $C$. аппиит genome database (http://cab.pepper.snu. ac.kr). Four BAC clones spanning the gaps of the scaffolds were fully shotgun sequenced by NICEM. Repeat sequences were filtered by RepeatMasker (http://www. repeatmasker.org) and JDotter (http://athena.bioc.uvic.ca). The gene coding regions were predicted with FGENESH (http://linux1.softberry.com) and BLASTX (https://blast. ncbi.nlm.nih.gov) to distinguish exon and intron regions of fully sequenced BAC clones. To verify the predicted genes in the target region, BLAST analysis was carried out at the Tomato Genome CDS database (ITAG release 2.40), SGN (http://solgenomics.net), and Pepper Annotation CM334 (V1.55) CDS database (http://cab.pepper.snu.ac.kr).

\section{Genotype analysis by high-resolution melting (HRM) and Kompetitive Allele Specific PCR (KASP) assays}

The HRM analysis was performed in a Rotor-Gene ${ }^{\mathrm{TM}}$ 6000 thermocycler (Corbett, Australia). HRM reactions were performed in a total volume of $20 \mu \mathrm{l}$ containing $60 \mathrm{mM} \mathrm{KCl}, 10 \mathrm{mM}$ Tris- $\mathrm{HCl}, 2.5 \mathrm{mM} \mathrm{MgCl} 2,0.25 \mathrm{mM}$ each dNTP, 5 pmol each primer, 1 unit Taq polymerase, $1.25 \mu \mathrm{M}$ Syto9 (Invitrogen, USA), and $50 \mathrm{ng}$ genomic DNA. Cycling conditions were as follows: $95{ }^{\circ} \mathrm{C}$ for $4 \mathrm{~min}$, followed by 45 cycles of $95{ }^{\circ} \mathrm{C}$ for $20 \mathrm{~s}, 58^{\circ} \mathrm{C}$ for $20 \mathrm{~s}$, and $72{ }^{\circ} \mathrm{C}$ for $40 \mathrm{~s}$. HRM was run at $0.1{ }^{\circ} \mathrm{C}$ increments between 70 and $90{ }^{\circ} \mathrm{C}$. Primers used in the HRM analysis are listed in Table S1. Linkage analysis of the markers developed in this study was performed with CarthaGene software (de Givry et al. 2005) using $C$. chinense $\mathrm{F}_{2}$ populations. KASP assays were performed to screen $1433 \mathrm{~F}_{2}$ individuals using four KASP markers. Primer sequences are listed in Table S1. KASP assays were run in a reaction volume containing a $5 \mu 1 \mathrm{KASP}$ 
Master Mix (KBiosciences, Herts England), $0.14 \mu 1$ primer mix and $5 \mu 150 \mathrm{ng} / \mu 1$ genomic DNA. The PCR conditions for the KASP marker assay was $94{ }^{\circ} \mathrm{C}$ for 15 min, followed by 10 cycles of touch down PCR from 61 to $55{ }^{\circ} \mathrm{C}$ with a $0.6{ }^{\circ} \mathrm{C}$ decrease per cycle, then followed by 26 cycles of $94{ }^{\circ} \mathrm{C}$ for $20 \mathrm{~s}$ and $57^{\circ} \mathrm{C}$ for $1 \mathrm{~min}$. To increase the reliability of the genotyping clusters, a further thermal cycling of the KASP chemistry containing 3 cycles of $94{ }^{\circ} \mathrm{C}$ for $20 \mathrm{~s}$ and $57^{\circ} \mathrm{C}$ for $1 \mathrm{~min}$ was added at the end. For genotyping, endpoint genotyping analyses were performed using the Light Cycler $^{\circledR} 480$ Real-Time PCR System (Roche, Germany).

\section{RNA-seq library construction and data analysis}

For RNA-seq library construction, 63 phenotypically wild-type and 30 phenotypically mutant plants from $\mathrm{F}_{2}$ populations exposed to $20{ }^{\circ} \mathrm{C}$ for 14 days were used. Total RNA was extracted from young leaves using TRIzol reagent (Invitrogen, Carlsbad, CA, USA) according to the manufacturer's instructions. RNA concentrations and purity were verified for each sample with a NanoDrop 2000 spectrophotometer (Thermo scientific, Waltham, MA, USA). A strand-specific RNA-seq library was constructed as described by Zhong et al. (2011). Briefly, $5 \mu \mathrm{g}$ total RNA was used for poly(A) RNA enrichment. First-strand and second-strand cDNA was generated using Superscript III reverse transcriptase (Invitrogen, Carlsbad, CA, USA). cDNA was purified by AMpure XP beads (Beckman-Coulter, Pasadena, CA, United States). Following TruSeq adapter ligation, the cDNA was amplified by PCR with 15 reaction cycles. Six random PCR primers were used in this step to obtain short sequence reads. Samples were prepared in three replicates and stored at $-20{ }^{\circ} \mathrm{C}$. Sample libraries were sequenced using Hiseq 2500 (Illumina/Solexa, San Diego, CA, USA) at NICEM. Sequence reads were aligned to the pepper transcriptome and genome using CLC Genomics Workbench 6.0 (CLC bio, Prismet, Denmark). The Counts program was used to analyze the number of reads aligning to annotated pepper genes. Expression values in reads per kilobase transcript per million (RPKM) were calculated for the single map and primary map data sets. Differentially expressed genes were identified using IDEG6 software (Romualdi et al. 2003).

\section{RT-PCR and qPCR analyses}

Two $\mu \mathrm{g}$ total RNA was reverse transcribed to cDNA using an oligo(dT) primer and M-MLV reverse transcriptase (Promega, Madison, USA). cDNA samples were diluted four times for the following test. Gene-specific primers used for RT-PCR and qPCR were designed based on the predicted gene sequences from the target region using the IDT (Integrated DNA Technology) qPCR primer design tool (Table S3). RT-PCR was performed in a total volume of $25 \mu \mathrm{l}$ containing $4 \mu \mathrm{l}$ of the diluted cDNA sample, $2.5 \mu 110 \times$ PCR buffer, $2.0 \mu 12.5 \mathrm{mM}$ dNTP mix, $0.5 \mu 1$ each $10 \mathrm{pmol} / \mu 1$ primer, $0.25 \mu 1$ Taq polymerase (1U), and $15.25 \mu \mathrm{l}$ distilled water. PCR conditions involved initial denaturation for $5 \mathrm{~min}$ at $94{ }^{\circ} \mathrm{C}$, followed by 30 cycles of $20 \mathrm{~s}$ at $94{ }^{\circ} \mathrm{C}, 20 \mathrm{~s}$ at $62{ }^{\circ} \mathrm{C}$, and $20 \mathrm{~s}$ at $72{ }^{\circ} \mathrm{C}$, and a final extension of 5 min at $72{ }^{\circ} \mathrm{C}$.

qPCR primers specificity and amplification efficiency were verified by melting curve analysis (after 55 cycles), agarose gel electrophoresis, and sequencing. The qPCR reaction was performed in a Light Cycler $^{\circledR} 480$ Real-Time PCR System (Roche, Germany) with a $20-\mu 1$ reaction mixture containing $4 \mu \mathrm{l}$ diluted cDNA sample, $2.0 \mu 110 \times$ PCR buffer (TaKaRa, Japan), $2.0 \mu 12.5 \mathrm{mM}$ dNTP mix, $0.5 \mu \mathrm{l}$ each $10 \mu \mathrm{M}$ forward and reverse primer, $0.4 \mu \mathrm{l}$ rTaq (5 units, TaKaRa, Japan), $0.5 \mu 150 \mu \mathrm{M}$ Syto9 and $10.1 \mu \mathrm{l}$ distilled water. The following PCR cycling conditions were used for qPCR analysis: initial preincubation at $95{ }^{\circ} \mathrm{C}$ for $5 \mathrm{~min}$, followed by 50 cycles of denaturation at $95^{\circ} \mathrm{C}$ for $10 \mathrm{~s}$, annealing at $62{ }^{\circ} \mathrm{C}$ for $10 \mathrm{~s}$ and extension at $72{ }^{\circ} \mathrm{C}$ for $20 \mathrm{~s}$. The pepper actin gene was used as the internal control. Relative gene expression levels were calculated using the advanced relative quantification method as implemented with Light Cycler $^{\circledR} 480$ Real-Time PCR System (Roche, Germany).

\section{GO term enrichment analysis}

Analysis of enriched gene ontology (GO) terms was performed for 626 differentially expressed pepper genes with the Blast2GO program using gene annotations downloaded from the NCBI database. Mapping and annotation were performed using default parameters ( $E$ value hit filter of $1.0 \mathrm{e}^{-6}$, annotation cutoff of 55, and GO weight of 5).

\section{Results}

\section{Analysis of inheritance of low temperature sensitivity}

To develop a high-density map for the $s y-2$ gene, $\mathrm{F}_{1}$ and $\mathrm{F}_{2}$ individuals derived from a cross between ' $s y-2$ ' and 'No. 3341 ' were evaluated for their response to low temperature after exposure to cold stress $\left(20^{\circ} \mathrm{C}\right)$ for 2 weeks in a growth chamber. All ten $\mathrm{F}_{1}$ plants showed a normal phenotype. The $1020 \mathrm{~F}_{2}$ plants segregated 788 normal and 232 abnormal phenotypes, which fits a $3: 1$ ratio $\left(\chi^{2}=2.77\right.$, $P=0.10$ ), confirming the recessive nature of $s y-2$ (Fig. 1; Table 1). These results were consistent with earlier studies (An et al. 2011; Koeda et al. 2013). 


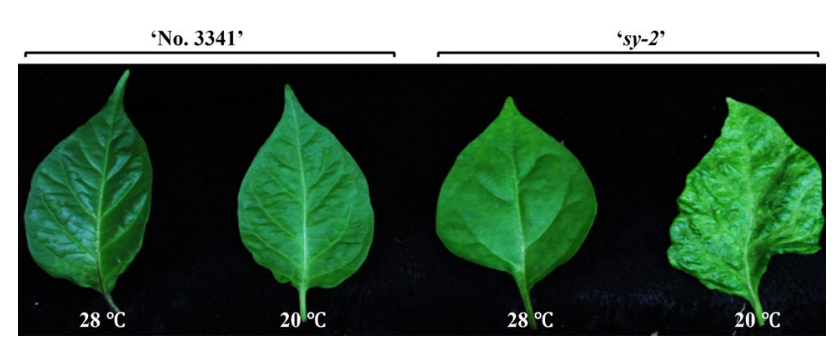

Fig. 1 Comparison of phenotypes of 'No. 3341' and 'sy-2' grown at different temperatures $\left(20\right.$ and $\left.28^{\circ} \mathrm{C}\right)$. Fourteen days after low temperature exposure, chlorophyll-deficient, rutted, and shrunken leaves could be observed in 'sy-2' whereas 'No. 3341' showed normal leaves

\section{Synteny analysis between the pepper genetic map and the tomato genome}

The sy-2 locus has previously been mapped to the long arm of tomato and pepper chromosome 1 between the markers C2_At1g09070 and C2_At4g29120 (An et al. 2011). A tomato scaffold sequence (C01HBa0051C14) of 126,295 bp covering the corresponding region of the $s y-2$ locus of pepper was obtained from SGN (http://solgenomics.net) based on the sequence of the C2_At1g09070 and C2_At4g29120 markers. Tomato scaffold sequences were used to BLAST search a $C$. annuиm 'CM334' V1.5 scaffold database to identify homologous pepper sequences. Based on the homology search, three non-overlapping pepper scaffold sequences, scaffold $2607(377.7 \mathrm{~kb})$, scaffold $3515(200.8 \mathrm{~kb})$, and scaffold $2510(318.6 \mathrm{~kb})$, representing the $s y$ - 2 locus were identified.

\section{Marker development}

In our previous study, to determine the chromosomal location of the sy-2 gene, 91 COSII markers were used to map 12 pepper linkage groups in an $\mathrm{F}_{2}$ population (total 108 individuals) derived from wild-type 'No. 3341' and mutant 'sy-2'. Among them, six COSII markers (COS634,
COS511, COS17, COS18, COS211, and COS22) were found to be linked to the $s y-2$ gene (An et al. 2011). The closest flanking markers, COS511 and COS634, were approximately 1.6 and $3.1 \mathrm{cM}$ away from the $s y-2$ locus (Fig. 2a). Since relatively few markers have been mapped on tomato and pepper chromosome 1 between these two markers, a high-resolution genetic map was generated for the $s y$-2 locus using eight SNP markers (HRM based) and four KASP markers. SNP markers were designed in intergenic regions based on sequence information derived from the three CM334 scaffold sequences, scaffold 2607, scaffold 3515, and scaffold 2510. Details of these markers are shown in Table S1. Our initial mapping effort identified 16 new markers for the $s y-2$ locus from which twelve markers were used for genotyping: three KASP markers (KASP 634, KASP 1-3, and KASP 1-2) from scaffold 2607, four SNP markers (SNP 2-4, SNP2-1, SNP 3-6, and SNP 5-5) from scaffold 3515, and one KASP marker (KASP 511) and four SNP markers (SNP 3-12, SNP 5-1, SNP 3-8, and SNP 3-7) from scaffold 2510.

\section{BAC library screening and marker enrichment}

There were two sequence gaps in the target region: the first one was between scaffold 2607 and 3515 (200.8 kb), and the second one was between scaffold 3515 and 2510 (Fig. S1). BAC sequences were explored to fill the gaps between the non-overlapping pepper scaffold sequences. Seven primer pairs (gap 2-1, gap 3-6, gap 3-1, gap 3-3-2, gap 4-3, gap 4-5, and gap 4-1; Table S2) derived from scaffold ends were used for screening a $C$. anпиит 'CM334' BAC library (Yoo et al. 2003). BAC library screening yielded fourteen positive BAC clones $(422 \mathrm{~K} 18,547 \mathrm{H} 22,534 \mathrm{~N} 9,343 \mathrm{~L} 4$, 331K22, 551K8, 551I9, 564P1, 679P23, 286C6, 555C12, 319A14, 586F23, and 444J2) (Fig. S1). Four BAC clones (422K18, 547H22, 534N9, and 343L4), which covered the gap between scaffolds 3515 and 2510, were completely sequenced. Based on the BAC clone sequencing result,
Table 1 The phenotype segregation analysis of $C$. chinense 'No. 3341', $C$. chinense 'sy-2', $\mathrm{F}_{1}$ and $\mathrm{F}_{2}$ populations

\begin{tabular}{|c|c|c|c|c|c|c|}
\hline \multirow[t]{2}{*}{ Population } & \multicolumn{3}{|c|}{ Number of plants } & \multirow[t]{2}{*}{ Expected ratio $(\mathrm{W}: \mathrm{M})^{\mathrm{a}}$} & \multirow[t]{2}{*}{$X^{\mathrm{b}}$} & \multirow[t]{2}{*}{$P^{\mathrm{c}}$} \\
\hline & Total & Wild-type & Mutant & & & \\
\hline ‘No. 3341’' & 10 & 10 & 0 & - & - & - \\
\hline 'sy-2' & 10 & 10 & 0 & - & - & - \\
\hline $\mathrm{F}_{1}\left({ }^{\prime}\right.$ No.3341' $\times$ 'sy-2’) & 10 & 10 & 0 & $1: 0$ & - & - \\
\hline $\mathrm{F}_{2}\left({ }^{\prime}\right.$ No.3341' $\times$ 'sy-2') & 1020 & 788 & 232 & $3: 1$ & 2.77 & 0.10 \\
\hline
\end{tabular}


a
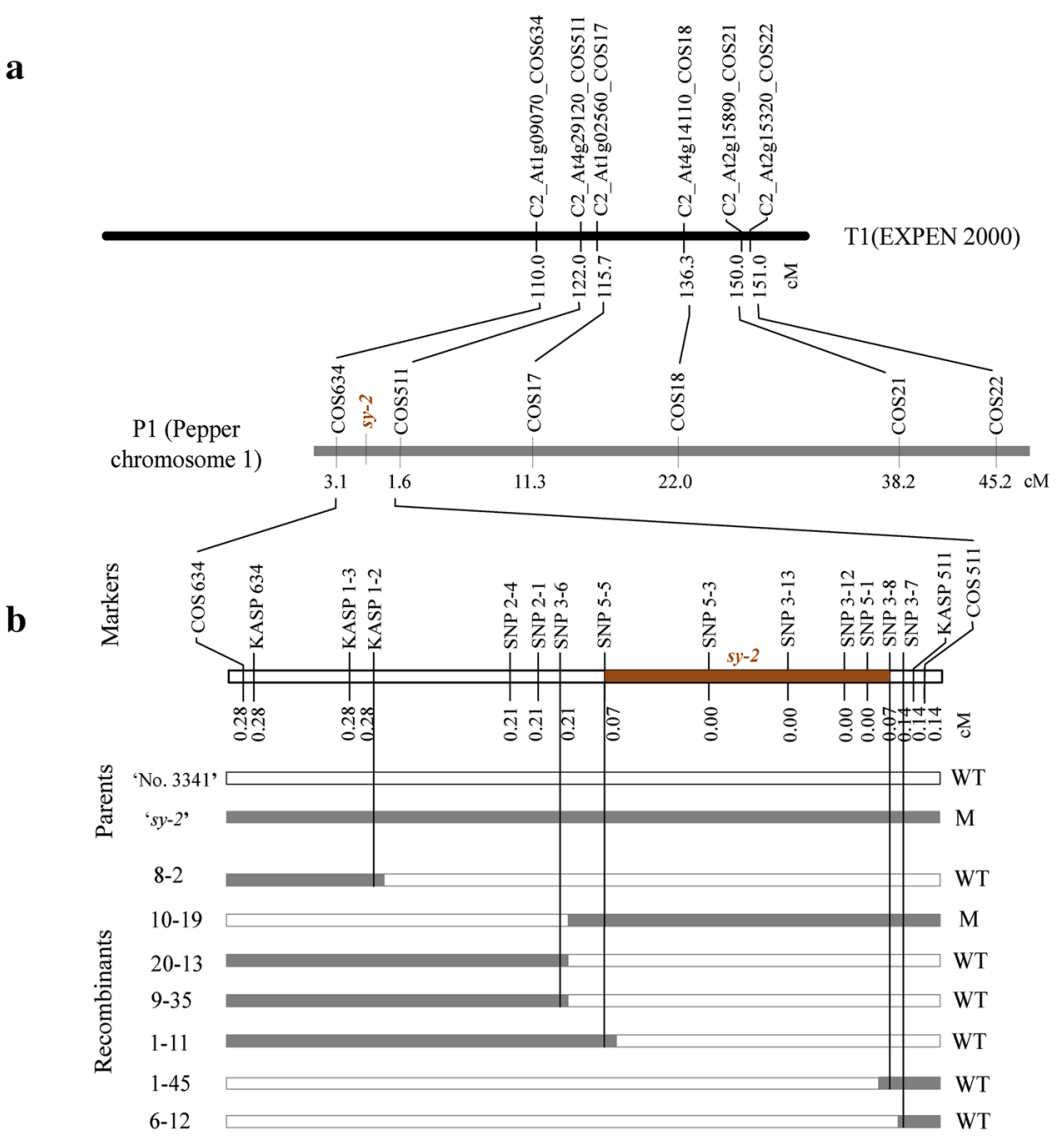

c $\quad \mathrm{CM} 334$

Scaffold

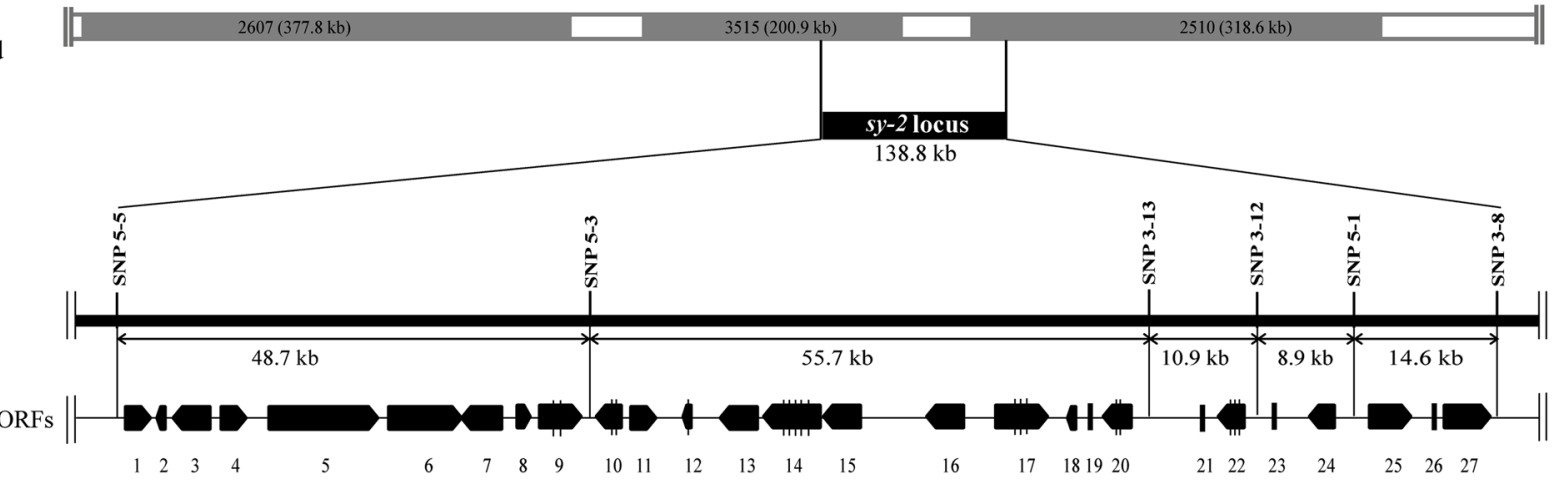

Fig. 2 Fine mapping of the $s y-2$ locus. a The location of the $s y$ 2 locus on pepper chromosome 1 between COSII marker $\mathrm{C} 2$ At1g09070 and C2_At4g29120 based on An et al. (2011). Markers on the Tomato-EXPEN 2000 chromosome 1 and pepper chromosome 1 are partially shown here. b Eight SNP markers and four KASP markers linked to the sy-2 locus are indicated next to the $C$. аnnиит scaffold region. Numbers on the left indicate genetic distances (cM). White rectangles represent the corresponding fragments of pepper (C. chinense 'No. 3341') chromosome 1, and black rectangles indicate the 'sy-2' chromosome 1 . The $s y$-2 gene was located between markers SNP 5-5 and SNP 3-8. c The $s y-2$ locus was delimited to a $138.8-\mathrm{kb}$ region between the SNP 5-5 and SNP 3-8 markers on the $C$. annuиm 'CM334' scaffolds (scaffold 3515 and 2510). Twenty-seven genes (ORF1 to ORF27) were predicted in the target region based on FGENESH analysis. Open rectangles represent the gaps in the pepper chromosome 1 scaffold region; the long black rectangle represents the target region. Small black rectangles with arrowheads indicate the 27 predicted ORFs in the target regions. SNPs identified in the predicted genes are indicated with vertical bars 
two additional SNP markers (SNP 5-3 and SNP 3-13) were developed to delimit the $s y-2$ locus.

\section{Fine mapping of the $s y-2$ locus}

To narrow down the target region of the $s y-2$ locus, genotype screening was performed using these newly developed markers. A mapping population with 1433 breeding lines was used for fine mapping analysis, from which seven recombinant plants $(8-2,10-19,20-13,9-35,1-11$, 1-45, and 6-12) were identified, one recombinant for each of KASP 1-2, SNP 5-5, SNP 3-7, and SNP 3-8, and three recombinants for SNP 3-6 (Fig. 2b). Among the fourteen markers used, four SNP markers, SNP 5-3, SNP 3-13, SNP 3-12, and SNP 5-1, were found to be at a genetic distance of $0 \mathrm{cM}$ from the $s y-2$ locus. Eight markers (KASP 634, KASP 1-3, KASP 1-2, SNP 2-4, SNP 2-1, SNP 3-6, and SNP 5-5) were located on one end of the $s y-2$ gene and two markers (SNP 3-8 and SNP 3-7) were on the other end. The $s y-2$ locus was thus delimited to a $0.14 \mathrm{cM}$ region between SNP 5-5 and SNP 3-8 markers on scaffold 3515 and 2510, and SNP 3-12, SNP 5-3, SNP 3-13, and SNP 5-1 markers were located within the $s y-2$ locus (Fig. 2b).

\section{Prediction of candidate genes}

Based on the fine mapping results, the $s y-2$ gene was delimited to a 138.8-kb region between the SNP 5-5 and SNP 3-8 markers (Fig. 2c). Twenty-seven genes (ORF1 to ORF27) were predicted in the target region based on FGENESH analysis, and BLASTP searches carried out at the NCBI BLAST server (http://blast.ncbi.nlm.nih.gov/ Blast.cgi) revealed that these genes were likely associated with diverse cellular functions (Fig. 2c; Table 2). These predicted genes encoded putative microrchidia (MORC) family proteins (ORF1, ORF4, and ORF5), polyproteins (ORF2, ORF14, and ORF17), cullin-like isoform $\mathrm{X} 1$ (ORF6), F-box family proteins (ORF10, ORF20, and ORF24), transposase family protein (ORF11), preprotein translocase subunit SecY (ORF13), geranylgeranyl pyrophosphate synthase protein (ORF19), pentatricopeptide repeat-containing protein $(O R F 23)$, sucrose nonfermenting 4-like protein-like (ORF25 and $O R F 27)$, and several putative uncharacterized proteins (ORF3,ORF7, ORF8, ORF9, ORF12, ORF15, ORF16, and ORF26). The sy-2 target region was further analyzed to find homologs of candidate genes from the tomato and pepper genomes. Homologs of ORF1, ORF4, ORF5, ORF6, ORF10, ORF11, ORF12, ORF18, ORF19, ORF20, ORF23, ORF24, ORF25, and ORF27 were identified by BLAST searches at the Tomato Genome CDS (ITAG release 2.40) and Pepper Annotation CM334 (V1.55) CDS database (Table S4).
The SCF complex, which is a multi-protein E3 ubiquitin ligase complex formed by four major components: an S-phase kinase-associated protein 1 (SKP1), Cullin 1 (CUL1), RING-box 1 (RBX1), and an F-box protein, mediates the ubiquitination of proteins destined for proteasomal degradation (Jain et al. 2007; Lyzenga and Stone 2012; Schumann et al. 2011; Vierstra 2009). Interestingly, four putative genes, ORF6 (encoding cullin-like isoform X1), ORF10, ORF20, and ORF24 (encoding F-box proteins) related to the SCF complex were identified within the $s y-2$ locus. ORF 10 and ORF 20 shared 93.4 and $90.0 \%$ nucleotide and amino acid sequence identity, respectively. ORF 24 (F-box/LRR-like protein) shared no significant sequence similarity with either ORF10 or ORF20. F-box proteins contain a highly conserved approximately 50 -amino acid F-box motif at their N-terminus, and $\mathrm{C}$-terminal proteinprotein interaction domains, such as kelch repeats, DEAD box, leucine-rich repeats, WD40 repeats, or Armadillo (Schumann et al. 2011; Jain et al. 2007; Vierstra 2009). The predicted protein sequences of ORF10 and ORF20 showed putative $\mathrm{C}$-terminal kelch repeats containing domain in addition to the N-terminal F-box domain, whereas ORF24 likely encoded a truncated F-box protein as it was lacking the F-box domain (Fig. S2).

\section{Sequence variations of predicted genes}

Putative SNP sites were identified by comparing the coding sequences from wild-type and mutant plants. Sequence alignment showed two SNPs each in ORF9, ORF10, and ORF20, one SNP in ORF12, five SNPs in ORF14, and three SNPs each in ORF17 and ORF22 (Table 2). In ORF9, out of the two SNPs identified (T935C and A952G), only SNP A952G resulted in an amino acid change (I318T). In ORF10, both SNPs, T691C and A943G, caused amino acid changes, C231G and N315D, respectively. In ORF20, two consecutive SNPs, G767A and T768A caused an amino acid change, S256K. In ORF12, the T267G SNP caused an amino acid change, D89E. Out of five SNPs identified in ORF14 (A122G, G125A, T378C, T2205C, and G3163A), three SNPs A122G, G125A, and G3163A caused amino acid changes, N41S, R42Q, and Q1055R, respectively. Out of the three SNPs identified in ORF17 (A537G, C546T, and A547G), SNP A547G resulted in an amino acid change, I183V. The three SNPs in ORF22 (A655G, T856G, and G1144T) resulted in amino acid changes K219E, Y286D, and M382I, respectively.

\section{Expression analysis of predicted genes}

RT-PCR was carried out to identify which candidate genes showed a differential expression pattern between wild-type and mutant plants grown at two different temperatures, 


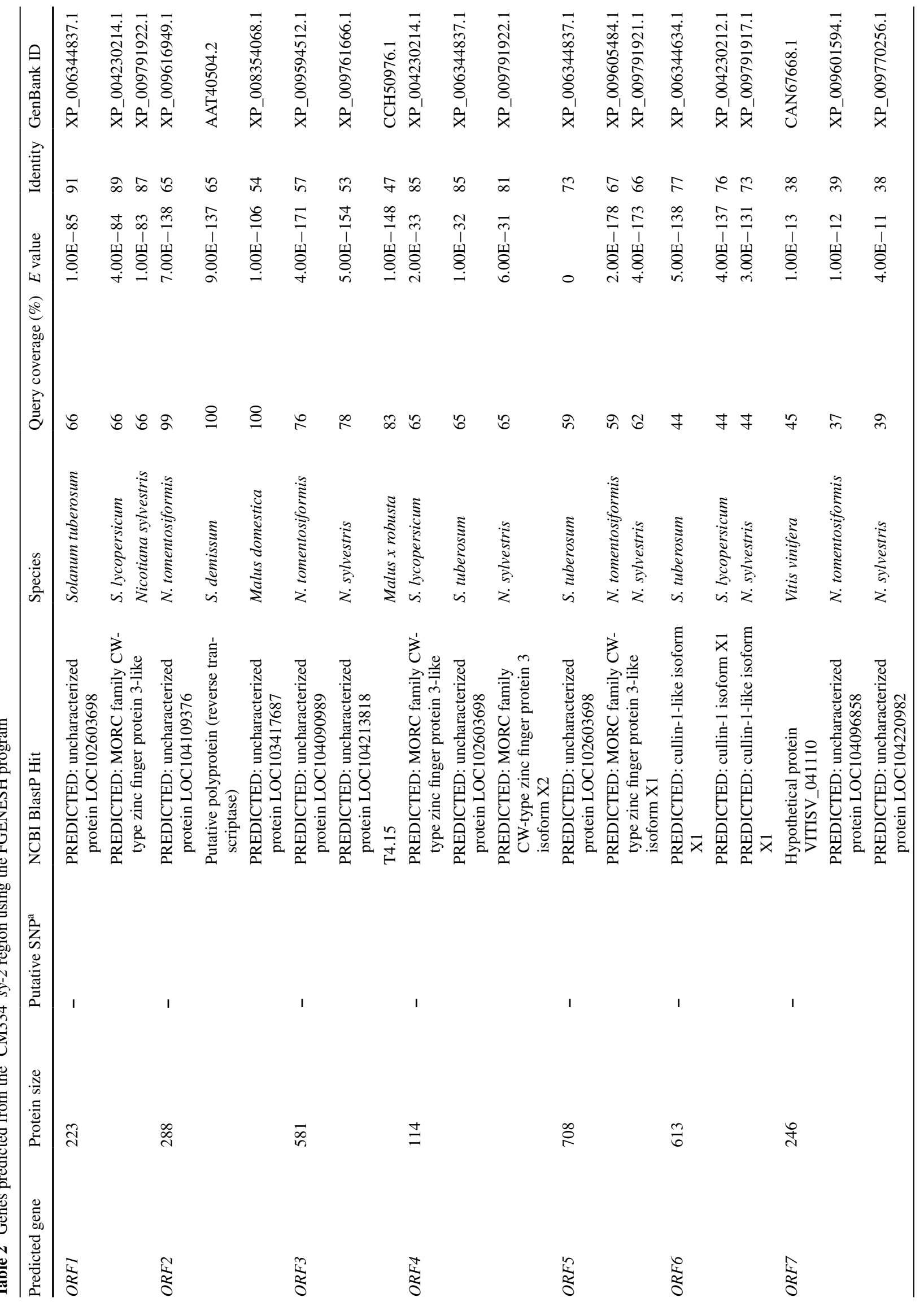




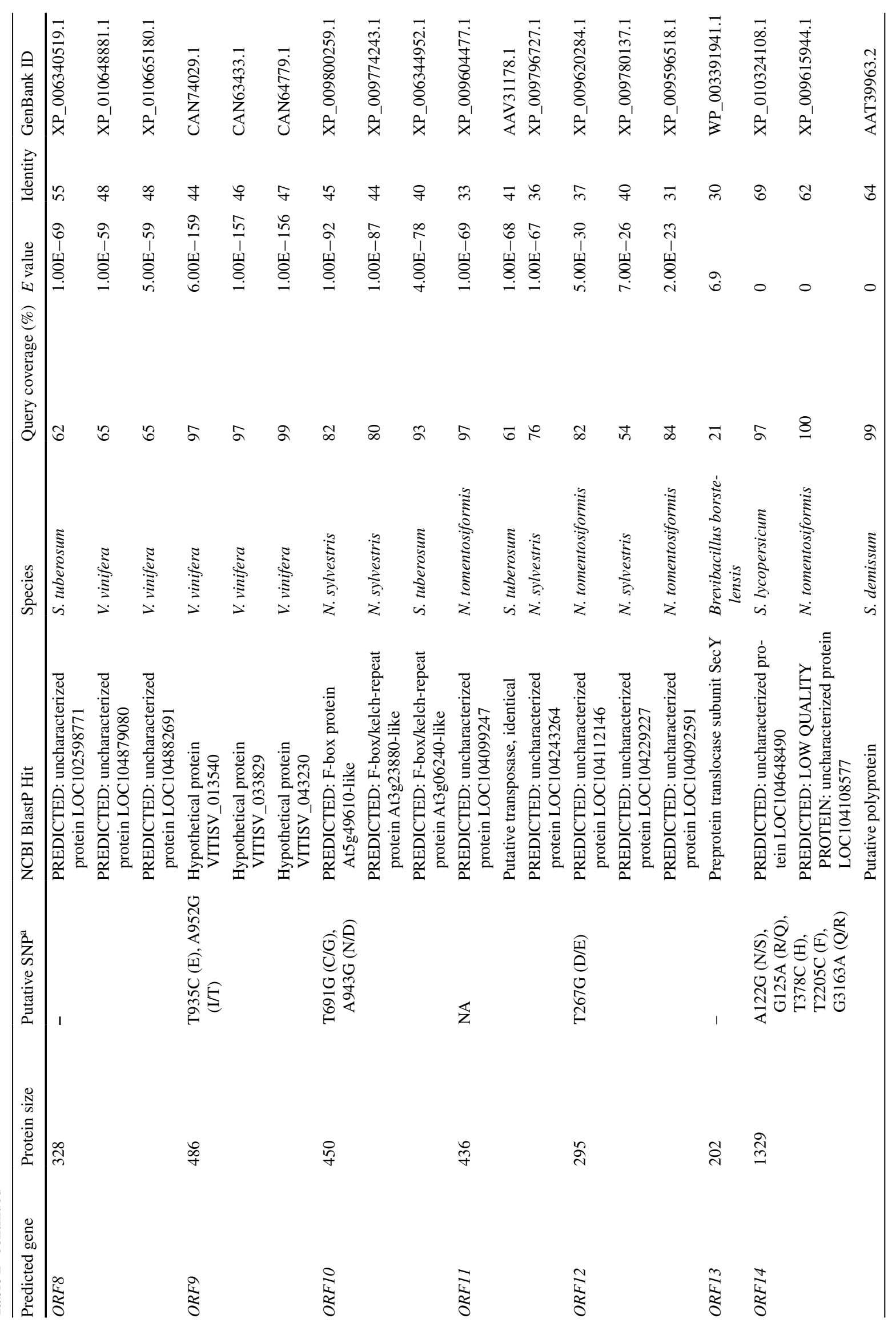




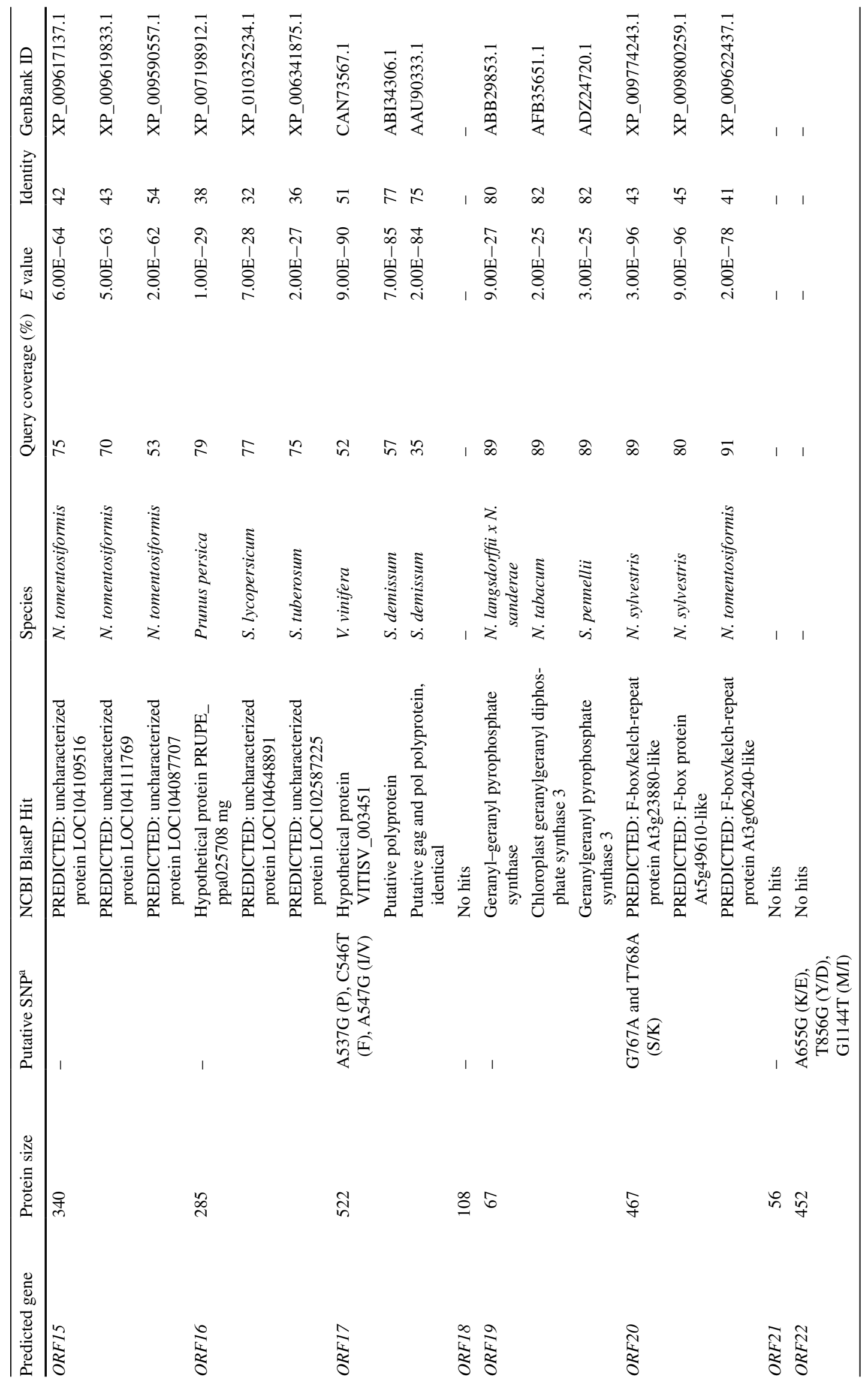




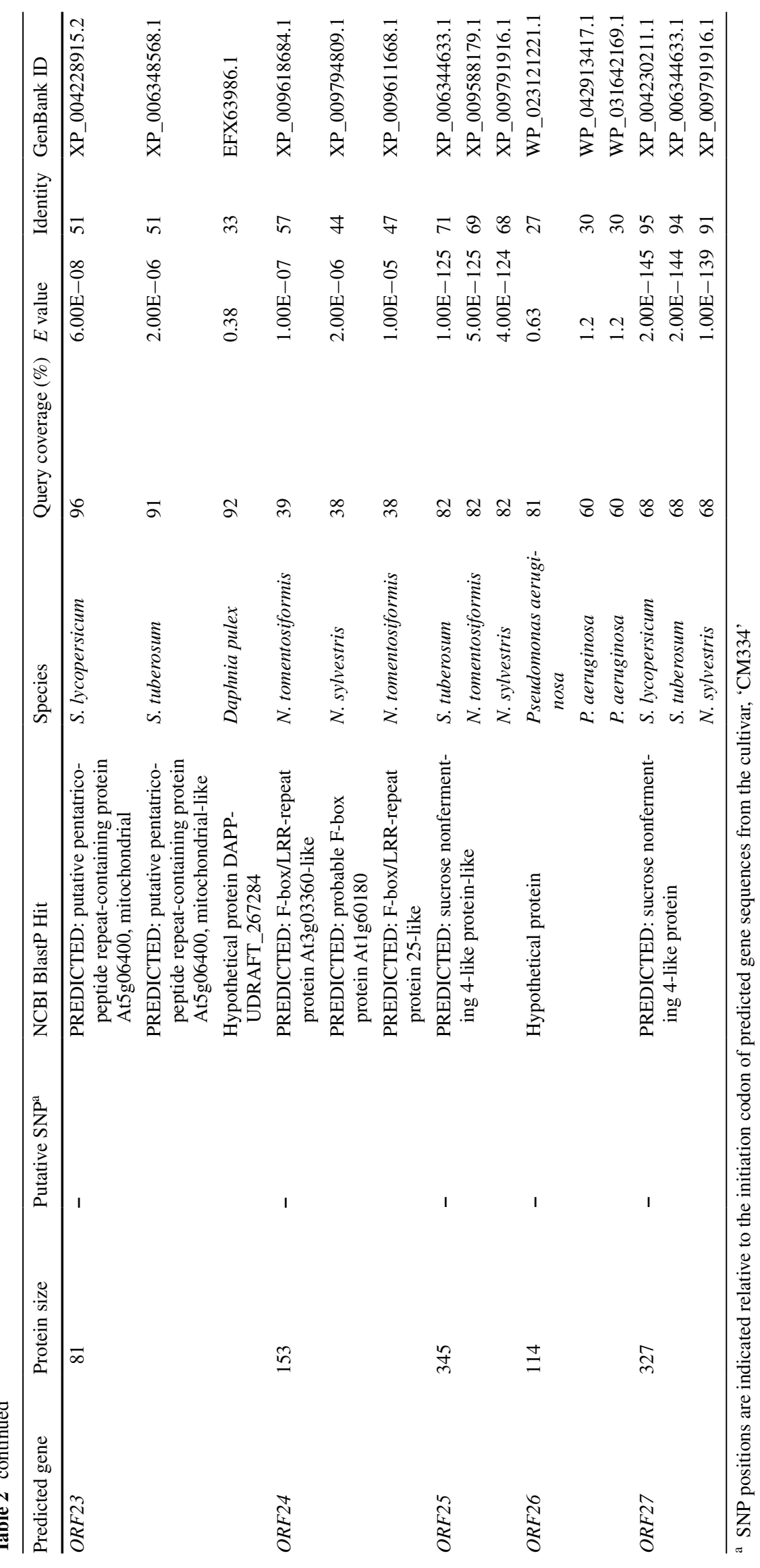


20 and $28{ }^{\circ} \mathrm{C}$. Several predicted genes from the $s y-2$ target region, ORF1, ORF2, ORF3, ORF4, ORF5, ORF6, ORF7, ORF13, ORF15, ORF18, ORF19, ORF21, ORF22, ORF24, ORF25, and ORF27, showed no expression differences between the wild-type and 'sy-2' plants (Fig. 3). Weak, but detectable expression was observed in the case of ORF11, ORF12, and ORF23 in both the wild-type and 'sy-2' plants. ORF9, ORF10, and ORF26 were downregulated in low temperature. However, the expression level of ORF10 was much higher in wild-type plants than in 'sy2' plants in both conditions. Several genes, ORF8, ORF14, $O R F 17$, and ORF20, were observed to be upregulated in both wild-type and 'sy-2' plants under cold stress, although the expression of ORF2O was higher in wild-type plants than 'sy-2' plants.

Based on these results, we next performed qPCR to investigate further the gene expression patterns of ORF10 and ORF20 (Fig. 4). Consistent with our RTPCR results, ORF10 and ORF20 showed differential expression between wild-type and mutant plants. Expression levels of ORF10 were 8.2 times higher in wild-type plants than in 'sy-2' plants at $20^{\circ} \mathrm{C}$. Similarly, expression levels of ORF10 were 8.9 times higher in wildtype plants than in 'sy-2' plants at $28{ }^{\circ} \mathrm{C}$. Expression of ORF2O was 1.2 and 1.8 times higher in wild-type plants compared with 'sy-2' plants at 20 and $28{ }^{\circ} \mathrm{C}$, respectively. Under low temperature, ORF10 was observed to be slightly downregulated, whereas $O R F 20$ was significantly upregulated, suggesting differential expression patterns under cold stress.

Overall, among the predicted $s y-2$ candidate genes, the ORF10 and ORF20 genes, which belong to the Kelch type F-box genes, were observed to be differentially expressed in wild-type and 'sy-2' plants. Expression levels of ORF10 and $O R F 20$ were significantly higher in wild-type plants. Furthermore, nonsynonymous mutations in the ORF10 and $O R F 2 O$ could affect their posttranslational modification and protein-protein interactions. F-box proteins, as a component of the SCF E3 ubiquitin ligase, play an important role in conferring substrate specificity to the SCF complex (Jain et al. 2007; Schumann et al. 2011; Skaar et al. 2013; Vierstra 2009). As such, F-box proteins play crucial roles in regulating various plant developmental and stress responses by integrating nearly all hormonal signaling pathways (Dreher and Callis 2007; Vierstra 2009; Kim et al. 2013; Li et al. 2016). These observations led us to propose that the F-box genes, ORF10 and ORF20, are likely $s y-2$ candidate genes, and differences in their expression levels and presence of nonsynonymous mutations could be responsible for the temperature sensitivity in 'sy-2' plants.

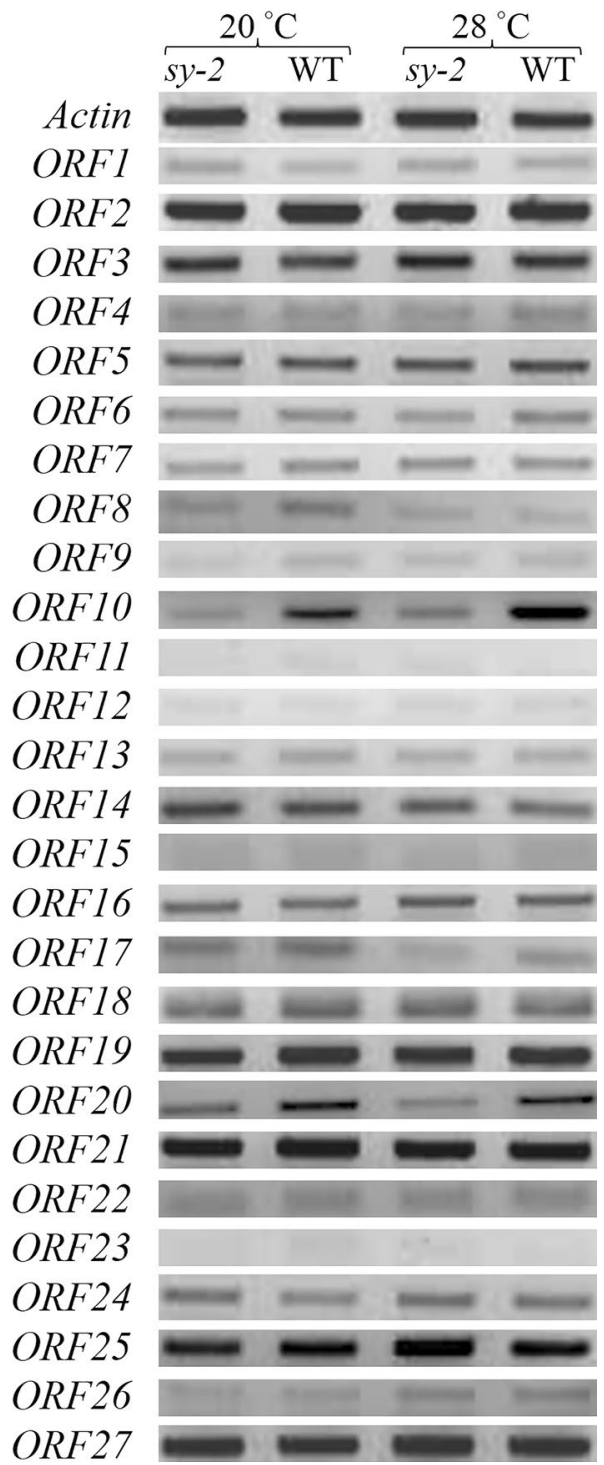

Fig. 3 RT-PCR analysis of the predicted $s y-2$ genes from 'No. 3341' and 'sy-2' plants grown under different temperatures $\left(20\right.$ and $\left.28^{\circ} \mathrm{C}\right)$. Actin was used as a control

\section{GO term enrichment analysis}

To identify potentially altered biological processes under low temperature in Capsicum, the top 626 differentially expressed genes identified by RNA-seq were used for GO term enrichment analysis (Fig. S3). These results showed that in the biological process category, cellular process, response to stimulus, single-organism process, and response to stress were the most highly represented groups, suggesting that major metabolic changes take place to maintain tissue activity in low temperature. In the cellular component category, transcripts that correspond to the cell, 
Fig. 4 qPCR analysis of predicted $s y$-2 genes from 'No. 3341 ' and 'sy-2' plants treated with different temperatures $\left(20\right.$ and $\left.28^{\circ} \mathrm{C}\right)$. Actin was used as an internal control. Different letters indicate significant differences within the groups (ORF10 and ORF20) according to Duncan's multiple range test $(P \leq 0.05)$. Error bars indicates standard error (SE)

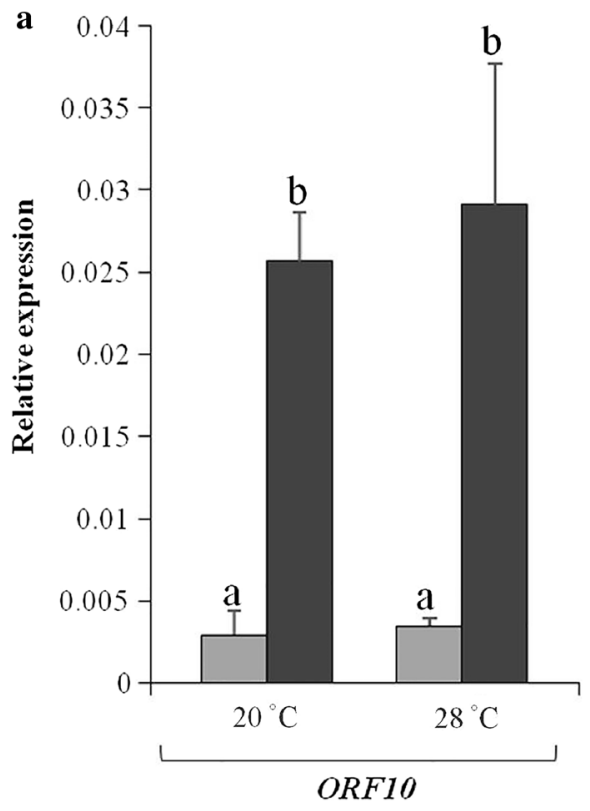

b $\square s y-2$ $\square$ WT

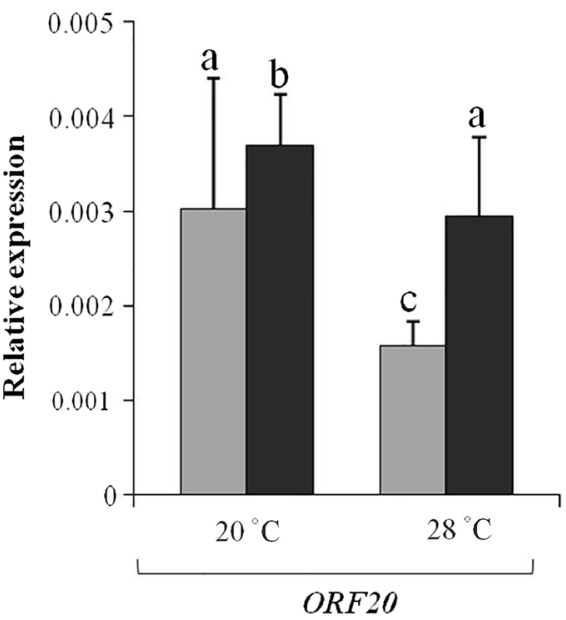

cell parts, intracellular, and intracellular part were typically the most enriched. This suggests that low temperature affects cellular components. Binding and catalytic activities were the two groups most highly enriched within the molecular function category, suggesting that posttranslational modifications might be involved in the regulation of expression of at least some of the stress-responsive genes to cope with low temperature.

\section{Discussion}

With the availability of whole genome sequence (WGS) and the development of saturating marker technologies, map-based cloning can now be performed at a higher resolution, and candidate genes can, therefore, be identified more efficiently. In the present study, based on high-resolution genetic mapping, we identified four SNP markers (SNP 5-3, SNP 3-13, SNP 3-12, and SNP 5-1) that co-segregate with the $s y-2$ gene with a resolution of $0 \mathrm{cM}$. Our results showed that the $s y-2$ gene was located between the SNP 5-5 and SNP 3-8 markers within a 138.8-kb region on chromosome 1 encompassing 27 putative genes. These genes were predicted to encode proteins associated with diverse biophysiological functions, although several of the predicted genes are homologs of putative uncharacterized proteins.

Among the $s y-2$ candidate genes, expression levels of two genes predicted to code F-box proteins and members of the SCF complex, ORF10 and ORF20, were significantly lower in ' $s y$-2' plants in both stressed and non-stressed conditions compared with wild-type plants. This finding raised the interesting possibility that these genes may be associated with the cold temperature stress response in the 'sy-2' pepper. Previously, two F-box genes were mapped to $C t b 1$, a quantitative trait locus (QTL) for cold tolerance in rice (Saito et al. 2004). Later studies showed that cold-sensitive rice plants (Hokkai241 and BT4-74-8) overexpressing an F-box protein with C-terminal kelch repeats from a cold-tolerant variety (Norin-PL8) exhibited cold tolerance (Saito et al. 2010). These results further suggest that the F-box genes ORF 10 and ORF 20 could be candidate genes for $s y-2$.

The SCF complex mediates the ubiquitination of proteins destined for proteasomal degradation, and participate in a wide range of plant developmental processes, such as hormone signaling, circadian rhythms, morphogenesis, embryo development, and senescence (Dezfulian et al. 2012; Jia et al. 2015; Kim et al. 2013; Li et al. 2016; Moon et al. 2004; Schumann et al. 2011; Stefanowicz et al. 2015; Zhang et al. 2015). Mutants of components of the multisubunit E3 ligases show broad pleiotropic effects on plant growth and development (Gray et al. 1999; Liu et al. 2004). For instance, Liu et al. (2004) demonstrated important roles for Arabidopsis Skp-like genes (ASKs), ASK1 and ASK2, in plant growth and development through analysis of the ask1 ask2 double mutant, which displayed developmental defects in embryogenesis and seedling growth caused by alterations in cell division, expansion, and elongation. In another study, male-sterility in an Arabidopsis mutant with abnormal microspores was found to be caused by an insertional mutation in the ASK1 gene (Yang et al. 1999). Mutations in AXR6, which encodes the SCF subunit CUL1, caused auxin-related defects throughout the plant life cycle (Hellmann et al. 2003). Taking these observations into account, the observed $s y-2$ mutant phenotype might be due 
to defects in the F-box genes and/or the impairment of their interaction with other SCF complex proteins. Furthermore, proteasome-mediated protein degradation plays a crucial role in plant adaptation to environmental changes and maintenance of homeostasis by degrading transcriptional activators or repressor proteins to regulate gene expression (Smalle and Vierstra 2004; Yan et al. 2013). Our study documented that the altered expression of many genes involved in biological processes, such as cellular process, response to stimulus, and response to stress, is associated with the pepper leaf abnormal phenotype under low temperature. This altered gene expression may be due to changes in proteasome-mediated protein degradation.

ORF10 and ORF2O were predicted to encode F-box proteins containing C-terminal kelch repeats with a high degree of conservation with other F-box/kelch proteins from plants (Fig. S2). Two amino acid changes were observed within the kelch repeats containing domain of the ORF10 gene from 'sy-2' mutant plants, which could affect protein-protein interactions (Jain et al. 2007; Schumann et al. 2011; Xu et al. 2009). Ubiquitination is a posttranslational modification process that mediates many aspects of plant growth and development (Lee and Kim 2011; Lyzenga and Stone 2012). Typically, substrate recognition by ubiquitin ligases requires an initial substrate modification through phosphorylation; F-box proteins recruit phosphorylated substrates to the SCF complex for ubiquitination (Skaar et al. 2013). However, it is possible that SCF can also be regulated through phosphorylation of the F-box protein itself (Kato et al. 2010; Santra et al. 2009). The mutation in the $O R F 20$-encoded protein causes an amino acid change from $\mathrm{S}$ to $\mathrm{K}$, raising the possibility that it may affect the phosphorylation status of the protein, its subsequent binding of the substrate to the SCF complex, and its ultimate degradation via the proteasome (Kato et al. 2010; Santra et al. 2009). Identification and validation of protein-protein interaction and regulatory sites are essential for understanding their functional consequences. Based on previous observations and those presented here, we suggest that the F-box genes ORF10 and ORF20 are the most likely candidates for the cold-sensitive $s y-2$ gene and are associated with abiotic stress responses in pepper. Further functional analysis of the ORF1O and ORF20 genes will help to unravel the molecular mechanism responsible for the $s y-2$ cold temperature growth phenotype.

In summary, in this study, a genetic and physical map of the temperature sensitivity gene $s y-2$ was constructed to identify the candidate gene for temperature sensitivity. Two putative F-box genes found in the $s y-2$ region were considered strong candidates for the $s y-2$ locus. 'sy2 ' plants exhibited abnormal phenotypes when exposed to low temperature $\left(20{ }^{\circ} \mathrm{C}\right)$ and showed lower expression levels of these F-box genes than wild-type plants, even at
$28{ }^{\circ} \mathrm{C}$, suggesting their function in growth and development under low temperature exposure. Recently, there has been remarkable progress in understanding the ubiquitinproteasome system and their roles in cellular processes. Biochemical and molecular studies have shown that these proteins can form complexes or supercomplexes to regulate the degradation of different cellular proteins. Therefore, we hypothesize that the $s y-2$ candidate F-box proteins and their interacting protein partners may serve an important role in plant growth and development under low temperature conditions. Further functional characterization of these F-box genes is warranted to resolve the molecular and physiological mechanisms of temperature sensitivity, and provide a basis for engineering temperature tolerance in plant species being cultivated in marginal climates. Furthermore, findings and resources generated herein will greatly facilitate marker-assisted selection for cold tolerance in pepper.

Author contribution statement LL, JV and YDJ participated in the design of the study, performed the DNA extractions, SNP genotyping, and drafted the manuscript. SK and MH developed mapping populations. JV and SG participated in revision of the manuscript. BCK participated in the conception of the study, discussion, and revision of the manuscript. All authors have read and approved the final version of manuscript.

Acknowledgments This research was supported by the Golden Seed Project (213002-04-3-CG900), the Ministry of Agriculture, Food and Rural Affairs (MAFRA), the Ministry of Oceans and Fisheries (MOF), the Rural Development Administration (RDA), and the Korea Forest Service (KFS), Republic of Korea, and a Grant (710001-07) from the Vegetable Breeding Research Center through the Agriculture, Food and Rural Affairs Research Center Support Program, Ministry of Agriculture, Food and Rural Affairs.

\section{References}

An SJ, Pandeya D, Park SW, Li JJ, Kwon JK, Koeda S, Hosokawa M, Paek NC, Choi D, Kang BC (2011) Characterization and genetic analysis of a low-temperature-sensitive mutant, sy-2, in Capsicum chinense. Theor Appl Genet 122:459-470

Arbona V, Manzi M, de Ollas C, Gómez-Cadenas A (2013) Metabolomics as a tool to investigate abiotic stress tolerance in plants. Int J Mol Sci 14:4885-4911

Chinnusamy V, Zhu J, Zhu JK (2007) Cold stress regulation of gene expression in plants. Trends Plant Sci 12:444-451

Chinnusamy V, Zhu JK, Sunkar R (2010) Gene regulation during cold stress acclimation in plants. Methods Mol Biol 639:39-55

de Givry S, Bouchez M, Chabrier P, Milan D, Schiex T (2005) Cartha gene: multipopulation integrated genetic and radiation hybrid mapping. Bioinformatics 21:1703-1704

Dezfulian MH, Soulliere DM, Dhaliwal RK, Sareen M, Crosby WL (2012) The SKP1-like gene family of Arabidopsis exhibits a high degree of differential gene expression and gene product interaction during development. PLoS ONE 7:e50984 
Dreher K, Callis J (2007) Ubiquitin, hormones and biotic stress in plants. Ann Bot 99:787-822

Dwivedi SL, Perotti E, Ortiz R (2008) Towards molecular breeding of reproductive traits in cereal crops. Plant Biotech J 6:529-559

Gray WM, del Pozo JC, Walker L, Hobbie L, Risseeuw E, Banks T, Crosby WL, Yang M, Ma H, Estelle M (1999) Identification of an SCF ubiquitin-ligase complex required for auxin response in Arabidopsis thaliana. Genes Dev 13:1678-1691

Harfied JL, Prueger JH (2015) Temperature extremes: effect on plant growth and development. Weather Clim Extremes 10:4-10

Havaux M, Kloppstech K (2001) The protective functions of carotenoid and flavonoid pigments against excess visible radiation at chilling temperature investigated in Arabidopsis $n p q$ and $t t$ mutants. Planta 213:953-966

Hellmann H, Hobbie L, Chapman A, Dharmasiri S, Dharmasiri N, del Pozo C, Reinhardt D, Estelle M (2003) Arabidopsis AXR6 encodes CUL1 implicating SCF E3 ligases in auxin regulation of embryogenesis. EMBO J 22:3314-3325

Hua J, Grisafi P, Cheng SH, Fink GR (2001) Plant growth homeostasis is controlled by the Arabidopsis BON1 and BAP1 genes. Genes Dev 15:2263-2272

Hwang J, Li J, Liu WY, An SJ, Cho H, Her NH, Yeam I, Kim D, Kang BC (2009) Doulble mutations in eIF4E and eIFiso4E confer recessive resistance to Chilli veinal mottle virus in pepper. Mol Cells 27:329-336

Ismail AM, Heuer S, Thomson MJ, Wissuwa M (2007) Genetic and genomic approaches to develop rice germplasm for problem soils. Plant Mol Biol 65:547-570

Jain M, Nijhawan A, Arora R, Agarwal P, Ray S, Sharma P, Kapoor S, Tyagi AK, Khurana JP (2007) F-Box proteins in rice. Genomewide analysis, classification, temporal and spatial gene expression during panicle and seed development, and regulation by light and abiotic stress. Plant Physiol 143:1467-1483

Jia FJ, Wang CY, Huang JG, Yang GD, Wu CG, Zheng CC (2015) SCF E3 ligase PP2-B11 plays a positive role in response to salt stress in Arabidopsis. J Exp Bot 66:4683-4697

Kato M, Kito K, Ota K, Ito T (2010) Remodeling of the SCF complex-mediated ubiquitination system by compositional alteration of incorporated F-box proteins. Proteomics 10:115-123

Kim HJ, Chiang YH, Kieber JJ, Schallera GE (2013) SCF ${ }^{\mathrm{KMD}}$ controls cytokinin signaling by regulating the degradation of type-B response regulators. Proc Natl Acad Sci USA 110:10028-10033

Koeda S, Hosokawa M, Kang BC, Yazawa S (2009) Dramatic changes in leaf development of the native Capsicum chinense from the Seychelles at temperature below $24{ }^{\circ} \mathrm{C}$. J Plant Res 122:623-631

Koeda S, Hosokawa M, Kang BC, Tanaka C, Choi D, Sano S, Shiina T, Doi M, Yazawa S (2012) Defense response of a pepper cultivar cv. Sy-2 is induced at temperatures below $24^{\circ} \mathrm{C}$. J Plant Res 125:137-145

Koeda S, Hosokawa M, Saito H, Doisss M (2013) Temperature-sensitive phenotype caused by natural mutation in Capsicum latescent in two tropical regions. J Plant Res 126:675-684

Lee JH, Kim WT (2011) Regulation of abiotic stress signal transduction by E3 ubiquitin ligases in Arabidopsis. Mol Cells 31:201-208

Li Y, Zhang L, Li DK, Liu ZB, Wang JM, Li XF, Yang L (2016) The Arabidopsis F-box E3 ligase RIFP1 play a negative role in abscisic acid signaling by facilitating ABA receptor RCAR3 degradation. Plant Cell Environ 39:571-582

Liu F, Ni W, Griffith ME, Huang Z, Chang C, Peng W, Ma H, Xie D (2004) The ASK1 and ASK2 genes are essential for Arabidopsis early development. Plant Cell 16:5-20

Lyzenga WJ, Stone SL (2012) Abiotic stress tolerance mediated by protein ubiquitination. J Exp Bot 63:599-616

Millerd A, McWilliam JR (1968) Studies on a maize mutant sensitive to low temperature I. Influence of temperature and light on the production of chloroplast pigments. Plant Physiol 43:1967-1972
Miquel MF, Browse JA (1994) High-oleate oilseeds fail to develop at low temperature. Plant Physiol 106:421-427

Miura K, Furumoto T (2013) Cold signaling and cold response in plants. Int J Mol Sci 14:5312-5337

Moon J, Parry G, Estelle M (2004) The ubiquitin-proteasome pathway and plant development. Plant Cell 16:3181-3195

Peng Y, Zhang Y, Lv J, Zhang J, Li P, Shi X, Wang Y, Zhang H, He $Z$, Teng S (2012) Characterization and fine mapping of a novel rice albino mutant low temperature albino 1 . J Genet Genomics 39:385-396

Ramegowd V, Senthil-Kumar M (2015) The interactive effects of simultaneous biotic and abiotic stresses on plants: mechanistic understanding from drought and pathogen combination. Plant Physiol 176:47-54

Romualdi C, Bortoluzzi S, D’Alessi F, Danieli GA (2003) IDEG6: a web tool for detection of differentially expressed genes in multiple tag sampling experiments. Physiol Genomics 12:159-162

Saito K, Hayano-Saito Y, Maruyama-Funatsuki W, Sato Y, Kato A (2004) Physical mapping and putative candidate gene identification of a quantitative trait locus $\mathrm{Ctb} 1$ for cold tolerance at the booting stage of rice. Theor Appl Genet 109:515-522

Saito K, Hayano-Saito Y, Kuroki M, Sato Y (2010) Map-based cloning of the rice cold tolerance gene Ctb1. Plant Sci 179:97-102

Samuelsen AI, Rickson FR, Mok DW, Mok MC (1997) A temperature-dependent morphological mutant of tobacco. Planta 201:303-310

Santra MK, Wajapeyee N, Green MR (2009) F-box protein FBXO31 mediates cyclin D1 degradation to induce G1 arrest after DNA damage. Nature 459:722-725

Schumann N, Navarro-Quezada A, Ullrich K, Kuhl C, Quint M (2011) Molecular evolution and selection patterns of plant F-Box proteins with C-terminal kelch repeats. Plant Physiol 155:835-850

Shinozaki K, Yamaguchi-Shinozaki K (2000) Molecular responses to dehydration and low temperature: differences and cross-talk between two stress signaling pathways. Plant Biol 3:217-223

Skaar JR, Pagan JK, Pagano M (2013) Mechanisms and function of substrate recruitment by F-box proteins. Nat Rev Mol Cell Biol 14:369-381

Smalle J, Vierstra RD (2004) The ubiquitin 26S proteasome proteolytic pathway. Annu Rev Plant Biol 55:555-590

Stefanowicz K, Lannoo N, Van Damme EJ (2015) Plant F-box proteins-judges between life and death. Crit Rev Plant Sci 34:523-552

Thakur P, Kumar S, Malik JA, Berger JD, Nayyar H (2010) Cold stress effects on reproductive development in grain crops: an overview. Environ Exp Bot 67:429-443

Theocharis A, Clement C, Barka EA (2012) Physiological and molecular changes in plants grown at low temperatures. Planta 235:1091-1105

Vierstra RD (2009) The ubiquitin-26S proteasome system at the nexus of plant biology. Nat Rev Mol Cell Biol 10:385-397

Wang JE, Liu KK, Li DV, Zhang YL, Zhao Q, He YM, Gong ZH (2013) A novel peroxidase CanPOD gene of pepper is involved in defense responses to Phytophtora capsici infection as well as abiotic stress tolerance. Int J Mol Sci 14:3158-3177

Xu GX, Ma H, Nei M, Kong HZ (2009) Evolution of F-box genes in plants: different modes of sequence divergence and their relationships with functional diversification. Proc Natl Acad Sci USA 106:835-840

Yan JB, Li HO, Li SH, Yao RF, Deng HT, Xie Q, Xie DX (2013) The Arabidopsis F-box protein CORONATINE INSENSITIVE1 is stabilized by $\mathrm{SCF}^{\mathrm{COL} 1}$ and degraded via the $26 \mathrm{~S}$ proteasome pathway. Plant Cell 25:486-498

Yang M, Hu Y, Lodhi M, McCombie WR, Ma H (1999) The Arabidopsis SKP1-LIKE1 gene is essential for male meiosis and 
may control homologue separation. Proc Natl Acad Sci USA 96:11416-11421

Yoo EY, Kim S, Kim YH, Lee CJ, Kim BD (2003) Construction of a deep coverage BAC library from Capsicum annuиm, 'CM334'. Theor Appl Genet 107:540-543

Zhang JT, Liu H, Sun J, Li B, Zhu Q, Chen SL, Zhang HX (2012) Arabidopsis Fatty Acid Desaturase FAD2 is required for salt tolerance during seed germination and early seedling growth. PLoS ONE 7:e30355
Zhang Y, Wang C, Lin Q, Gao F, Ma Y, Zhang M, Lin Y, Ma Q, Hua X (2015) Genome-wide analysis of phylogeny, expression profile and sub-cellular localization of SKP1-Like genes in wild tomato. Plant Sci 238:105-114

Zhong S, Joung JG, Zheng Y, Chen YR, Liu B, Shao Y, Xiang JZ, Fei Z, Giovannoni JJ (2011) High-throughput illumina strandspecific RNA sequencing library preparation. Cold Spring Harb Protoc 8:940-949 